\title{
IMPLEMENTASI PERMENSESNEG NO 14 TAHUN 2012 TENTANG STANDAR PELAYANAN KESEHATAN DASAR PADA BAGIAN PELAYANAN KESEHATAN, BIRO UMUM, KEMENTERIAN SEKRETARIAT NEGARA DI JAKARTA
}

\author{
Indah Wahyu Maesarini dan Yuni Subiyanti \\ Institut Ilmu Sosial Dan Manajemen STIAMI \\ indah.wm@stiami.ac.id dan yoseekie_yunzi@yahoo.com
}

\begin{abstract}
Abstrak. Negara menjamin persamaan hak dan kedudukan setiap warga Negara dalam memperoleh pelayanan. Namun dalam kenyataan, masih tampak berbagai bentuk kesulitan dalam memperoleh pelayanan baik berupa sulitnya prosedur pelayanan, lamanya waktu pelayanan dan sarana prasarana pelayanan. Dengan adanya birokrasi pelayanan yang tidak efektif dan efisien sangat menghambat proses pelayanan kesehatan kepada pejabat/pegawai beserta keluarga di Lingkungan Kementerian Seretariat Negara. Oleh karena itu, Menteri Sekretaris Negara menerbitkan Peraturan Menteri Sekretariat Negara Nomor 14 Tahun 2012 tentang Standar Pelayanan Unit Kerja di Lingkungan Kementerian Sekretariat Negara.

Penelitian ini dilakukan untuk mengetahui sejauh manakah implementasi Peraturan Menteri Sekretariat Negara Nomor 14 Tahun 2012 khususnya Standar Pelayanan Kesehatan Dasar pada Bagian Peyananan Kesehatan, Biro Umum, Kementerian Sekretariat Negara. Penelitian ini menggunakan pendekatan deskriptif kualitatif untuk lebih dapat mendeskripsikan pengimplementasian Standar Pelayanan Kesehatan Dasar pada Bagian Peyananan Kesehatan, Biro Umum, Kementerian Sekretariat Negara.

Kesimpulan yang diperoleh adalah Bagian Pelayanan Kesehatan, Biro Umum, Kementerian Sekretariat Negara bahwa kebijakan standar pelayanan kesehatan dasar belum dilaksanakan sepenuhnya sesuai dengan ketentuan yang ada. Namun hal tersebut tidak menghambat pelaksanaan pelayanan kesehatan kepada para pejabat/pegawai beserta keluarga di Lingkungan Kementerian Sekretariat Negara.
\end{abstract}

Kata Kunci: Implementasi, Standar Pelayanan, Kesehatan

Abstract. The government of Indonesia guarantees equal rights and status of every citizen in obtaining services. However, in reality, various problems still occurredsuch as complicated service procedures andthe length of time and infrastructure services. Ineffective and inefficient bureaucracy services hamper health service processes to officers/employees and their families in the Ministry of the State Secretariat. Therefore, the Minister of State Secretary issued the Ministerial Decree of the State Secretary No. 14 year 2012 regarding Service Standard of Working Unit in the Ministry of the State Secretariat.

The purpose of this study is to find out how the Ministerial Decree of the State Secretary No. 14 year 2012 is implemented, especially Basic Health Service Standard in the Division of Health Services, General Bureau, The Public Ministry of the State Secretariat. This research used a qualitative descriptive approach to describe the implementation of Basic Health Service Standard in the Division of Health Services, General Bureau, The Ministry of the State Secretariat.

The study found that the Division of Health Services, General Bureau, General Affairs, the Ministry of the State Secretariat has not implemented all the policies of basic health service standard. However, in most cases it does not hamper the implementation of health services to the officers/employees and their employees in The Ministry of the State Secretariat.

Keywords: Implementation, Service Standards, Health 
Di era reformasi pelayanan tidak dapat dipisahkan dengan kehidupan manusia, karenanya pelayanan sangat dibutuhkan dalam segala dimensi kehidupan sehingga standar pelayanan menjadi salah satu hal yang harus dilaksanakan dalam memberikan pelayanan publik. Standar pelayanan menjadi salah satu tolak ukur yang dijadikan pedoman dalam pemberian pelayanan kepada masyarakat, dengan adanya standar pelayanan dalam setiap pelayanan publik menjamin kualitas pelayanan yang diberikan kepada masyarakat serta mengatur hak dan kewajiban baik bagi masyarakat bagi penerima pelayanan maupun petugas sebagai pemberi pelayanan.

Sebagai unsur lembaga pemerintah pusat yang bertugas memberikan dukungan teknis dan administrasi kepada Presiden dan Wakil Presiden dalam menyelenggarakan kekuasaan negara, Kementerian Sekretariat Negara harus selalu meningkatkan kinerjanya agar semakin efektif, efisien, transparan, responsif, dan akuntabel. Upaya tersebut telah dilakukan antara lain dengan ditetapkannya Peraturan Menteri Sekretaris Negara Nomor 8 Tahun 2007 tentang Petunjuk Pelaksanaan Penyusunan Standar Pelayanan Sekretariat Negara Republik Indonesia, yang mewajibkan seluruh unit kerja di lingkungan Sekretariat Negara untuk menyusun standar pelayanan. Penyusunan standar pelayanan ini sejalan pula dengan program kerja reformasi birokrasi yang tengah digulirkan di lingkungan Kementerian Sekretariat Negara.

Menindaklanjuti Peraturan Menteri tersebut di atas, seluruh unit kerja di lingkungan Kementerian Sekretariat Negara telah menyusun standar pelayanan, yang seluruhnya berjumlah 152 standar.

Berdasarkan pengamatan penulis, diduga terdapat gejala permasalahan dalam pelaksanaan Standar Pelayanan Kesehatan Pelayanan Dasar karena sejak dikeluarkannya Standar Pelayanan Kesehatan Dasar pada Bagian Pelayanan
Pelayanan Kesehatan, dan telah ditetapkan dengan Peraturan Menteri Sekretaris Negara Nomor 14 Tahun 2012 tentang Standar Pelayanan Unit Kerja di Lingkungan Kementerian Sekretariat Negara Republik Indonesia. Pengguna pelayanan dari standar pelayanan tersebut mencakup seluruh unit kerja di lingkungan Kementerian Sekretariat Negara/instansi lain/masyarakat luas, serta pengguna pelayanan yang bersifat khusus, seperti Presiden, Wakil Presiden, Menteri Sekretaris Negara, Sekretaris Wakil Presiden, dan Deputi masing-masing, serta Tamu Negara.

Standar pelayanan ini merupakan pedoman bagi pelaksana pelayanan di lingkungan Kementerian Sekretariat Negara dalam melaksanakan pelayanan dan sebagai informasi bagi pengguna pelayanan di lingkungan Kementerian Sekretariat Negara dan/atau di luar Kementerian Sekretariat Negara, baik berasal dari instansi terkait maupun masyarakat luas. Diharapkan standar pelayanan ini dapat dilaksanakan dengan sebaik-baiknya dan penuh dengan tanggung jawab.

Standar Pelayanan Kesehatan Dasar menjadi pedoman bagi petugas pelayanan kesehatan pada Bagian Pelayanan Kesehatan dalam memberikan pelayanan kesehatan bagi pejabat/pegawai dan keluarga. Hal penting yang harus ada dalam pelaksanaan standar pelayanan kesehatan dasar pada bagian pelayanan kesehatan adalah adanya kesepakatan dan komitmen bersama antara seluruh petugas pelayanan kesehatan agar dapat melaksanakan standar pelayanan yang telah ada serta senantiasa dapat memberikan arahan kepada pejabat/pegawai dan keluarga yang datang untuk mendapatkan pelayanan kesehatan mengenai adanya standar pelayanan kesehatan dasar.

Kesehatan belum melakukan sosialisasi secara menyeluruh baik kepada petugas pelayanan maupun kepada pejabat/pegawai dan keluarga di lingkungan Kementerian Sekretariat Negara selaku penerima pelayanan kesehatan. Bentuk sosialisasi 
yang dilakukan hanya sebatas pemasangan papan alur pelayanan yang disertai waktu pelayanan pada setiap jenis pelayanan yang diberikan. Kurangnya sosialisasi mengenai adanya standar pelayanan kesehatan dasar menimbulkan beberapa masalah dalam pelaksanaan pelayanan kesehatan sehingga mengakibatkan belum terlaksananya standar pelayanan kesehatan dasar dalam memberikan pelayanan kesehatan serta terhambatnya proses pelayanan khususnya secara administrasi karena baik petugas maupun penerima pelayanan belum mengikuti alur pelayanan kesehatan yang telah ditetapkan dalam standar pelayanan kesehatan dasar.

\section{Tujuan Penelitian}

Tujuan penelitian adalah untuk mengetahui sejauh mana implementasi Peraturan Menteri Sekretaris Negara Nomor 14 tahun 2012 tentang Standar Pelayanan Kesehatan Dasar pada Bagian Pelayanan Kesehatan, Biro Umum, Kementerian Sekretariat Negara.

\section{KAJIAN LITERATUR}

Salah satu tahapan penting dalam siklus kebijakan publik adalah implementasi kebijakan. Implementasi sering dianggap hanya merupakan pelaksanaan dari apa yang telah diputuskan para pengambil keputusan, seolah-olah tahapan ini kurang berpengaruh. Akan tetapi dalam kenyataannya, tahapan implementasi menjadi begitu penting karena suatu kebijakan tidak akan berarti apa-apa jika tidak dapat dilaksanakan dengan baik dan benar. Dengan kata lain implementasi merupakan tahap suatu kebijakan dilaksanakan secara maksimal dan dapat mencapai tujuan kebijakan itu sendiri.

Menurut Riant Nugroho (2014: 657), "Implementasi kebijakan pada prinsipnya adalah cara agar sebuah kebijakan dapat mencapai tujuannya."

Model implementasi kebijakan yang digunakan dalam penelitian ini, yaitu model penelitian yang dikembangkan oleh George C. Edward III. Menurut Edward III (Agustino, 2016: 136) terdapat empat variabel yang mempengaruhi keberhasilan impelementasi suatu kebijakan, yaitu:

\section{Komunikasi}

Variabel pertama yang memengaruhi keberhasilan implementasi suatu kebijakan menurut Goerge C. Edward III adalah komunikasi. Komunikasi, menurutnya sangat menentukan keberhasilan pencapaian tujuan dari implementasi kebijakan publik. Implementasi yang efektif terjadi apabila para pembuat keputusan sudah mengetahui apa yang akan mereka kerjakan. Pengetahuan atas apa yang akan mereka kerjakan dapat berjalan apabila komunikasi berjalan dengan baik, sehingga setiap keputusan kebijakan dan peraturan impelementasi harus ditansmisikan (atau dikomunikasikan) kepada bagian personalia yang tepat. Selain itu, kebijakan yang dikomunikasikan pun harus tepat, akurat, dan konsisten. Komunikasi (atau pentransmisian informasi) diperlukan agar para pembuat keputusan dan para implementor akan semakin konsisten dalam melaksanakan setiap kebijakan yang akan diterapkan dalam masyarakat. Terdapat tiga indikator yang dapat dipakai dalam mengukur keberhasilan variabel komunikasi, yaitu:

a. Transmisi; penyaluran komunikasi yang baik akan dapat menghasilkan suatu implementasi yang baik pula. Seringkali yang terjadi dalam penyaluran komunikasi adalah adanya salah pengertian (misscommunication).

b. Kejelasan; komunikasi yang diterima oleh para pelaksana kebijakan (streetlevel-bureuarats) haruslah jelas dan tidak membingungkan (tidak ambigu/mendua). Ketidakjelasan pesan kebijakan tidak selalu mengahalangi impelementasi, pada tataran tertentu, para pelaksana membutuhkan kejelasan informasi dalam melaksanakan kebijakan agar tujuan yang hendak dicapai dapat diraih sesuai konten kebijakan. 
c. Konsistensi; perintah yang diberikan dalam melaksanakan suatu komunikasi haruslah konsisten (untuk diterapkan atau dijalankan). Ini karena jika perintah yang diberikan sering berubah-ubah, maka dapat menimbulkan kebingungan bagi pelaksana di lapangan.

\section{Sumber Daya}

Variabel kedua r yang
mempengaruhi
implementasi suatu kebijakan adalah
sumber daya. Sumber daya merupakan
hal penting lainnya dalam
mengimplementasikan kebijakan.
Indikator sumber daya terdiri dari
beberapa elemen, yaitu:

a. Staf; sumber daya utama dalam implementasi kebijakan adalah staf atau sumber daya manusia (SDM). Kegagalan yang sering terjadi dalam implementasi kebijakan salah satunya disebabkan oleh karena staf yang tidak mencukupi, memadai, ataupun tidak kompoten di bidangnya. Penambahan jumlah staf dan implementor saja tidak cukup, tetapi diperlukan juga kecukupan staf dengan keahlian dan kemampuan yang diperlukan (kompeten dan kapabilitas) dalam mengimplementasikan kebijakan atau melaksanakan tugas yang diinginkan oleh kebijakan itu sendiri.

b. Informasi; dalam implementasi kebijakan, informasi mempunyai dua bentuk, yaitu pertama informasi yang berhubungan dengan cara melaksanakan kebijakan. Implementor harus mengetahui apa yang harus mereka lakukan saat mereka diberi perintah. Kedua, informasi mengenai data kepatuhan dari para pelaksana terhadap peraturan dan regulasi pemerintah yang telah ditetapkan. Implementor harus mengetahui apakah orang yang terlibat di dalam pelaksanaan kebijakan tersebut patuh terhadap hukum. c. Wewenang; pada umumnya kewenangan harus bersifat formal agar perintah dapat dilaksanakan. Kewenangan merupakan otoritas atau legitimasi bagi para pelaksana dalam melaksanakan kebijakan yang ditetapkan secara politik. Ketika wewenang nihil, maka kekuatan para implementor dimata publik tidak terlegitimasi, sehingga dapat menggagalkan proses implementasi kebijakan. Tetapi dalam konteks yang lain, ketika wewenang formal tersebut ada, maka sering terjadi kesalahan dalam melihat efektivitas kewenangan. Di satu pihak, efektivitas akan menyurut manakala wewenang diselewengkan oleh para pelaksana demi kepentingannya sendiri atau demi kepentingan kelompoknya.

d. Fasilitas; fasilitas fisik juga merupakan faktor penting dalam implementasi kebijakan. Implementor mungkin memiliki staf yang mencukupi, mengerti apa yang harus dilakukan dan memiliki wewenang untuk melaksanakan tugasnya, tetapi tanpa adanya fasilitas pendukung (sarana dan prasarana) maka implementasi kebijakan tersebut tidak akan berhasil.

\section{Disposisi}

Variabel ketiga yang memengaruhi keberhasilan implementasi kebijakan adalah disposisi. Hal-hal penting yang perlu dicermati pada variabel disposisi adalah:

a. Efek Disposisi; Disposisi atau sikap pelaksana akan menimbulkan hambatan-hambatan yang nyata terhadap implementasi kebijakan bila personil yang ada tidak melaksanakan kebijakan-kebijakan yang diinginkan oleh pejabat-pejabat tinggi. Oleh karena itu, pemilihan dan pengangkatan personil pelaksana kebijakan haruslah orang-orang yang memiliki dedikasi pada kebijakan 
yang telah ditetapkan; lebih khusus bagi pada kepentingan warga.

b. Melakukan Pengaturan Birokrasi (staffing the bureaucracy); dalam konteks ini Edward III mensyaratkan bahwa implementasi kebijakan harus dilihat juga dalam hal pengaturan birokrasi. Ini merujuk pada penunjukan dan pengangkatan staf dalam birokrasi yang sesuai dengan kemampuan, kapabilitas dan kompetensinya. Selain itu, pengaturan birokrasi juga bermuara pada 'pembentukan' sistem pelayanan publik yang optimal, penilaian personil dalam bekerja, hingga metode bypassing personil.

c. Insentif; Edward III menyatakan bahwa salah satu teknik yang disarankan untuk mengatasi masalah kecenderungan para pelaksana adalah dengan memanipulasi insentif. Pada umumnya orang bertindak menurut kepentingan mereka sendiri, maka memanipulasi insentif oleh para pembuat kebijakan mempengaruhi tindakan para pelaksana kebijakan. Dengan cara menambah keuntungan atau biaya tertentu mungkin akan menjadi faktor pendorong yang membuat para pelaksana kebijakan melaksanakan perintah dengan baik. Hal ini dilakukan sebagai upaya memenuhi kepentingan pribadi (self interst) atau organisasi.

\section{Struktur Birokrasi}

Menurut George C. Edward III, yang mempengaruhi keberhasilan implementasi kebijakan publik adalah struktur birokrasi. Walaupun sumber daya untuk melaksanakan suatu kebijakan tersedia, atau para pelaksana kebijakan mengetahui apa yang seharusnya dilakukan, dan mempunyai keinginan untuk melaksanakan suatu kebijakan, kemungkinan kebijakan tersebut tidak dapat dilaksanakan atau direalisasikan karena terdapatnya kelemahan dalam struktur birokrasi. Kebijakan yang begitu kompleks menuntut adanya kerjasama banyak orang, ketika stuktur birokrasi tidak kondusif pada kebijakan yang tersedia, maka hal ini akan menyebabkan sumber daya-sumber daya menjadi tidak efektif dan menghambat jalannya kebijakan. Birokrasi sebagai pelaksana sebuah kebijakan harus dapat mendukung kebijakan yang telah diputuskan secara politik dengan jalan melakukan koordinasi dengan baik.

Dua karakteristik, menurut Edward III, yang dapat mendongkrak kinerja struktur birokrasi/organisasi kearah yang lebih baik, yaitu dengan melakukan :

Membuat Standar Operating
Prosedures (SOPs) yang lebih
fleksibel; SOPs adalah suatu
prosedur atau aktivitas terencana
rutin yang memungkinkan para
pegawai (atau pelaksana kebijakan
seperti aparatur, administrator, atau
birokrat) untuk melaksanakan
kegiatan-kegiatannya setiap harinya
(days-to-days politics) sesuai dengan
standar yang ditetapkan (atau standar
minimum yang dibutuhkan warga).

b. Melaksanakan Fragmentasi, tujuannya untuk menyebar tanggung jawab berbagai aktivitas, kegiatan, atau program pada beberapa unit kerja yang sesuai dengan bidangnya masing-masing. Dengan terfragmentasinya struktur birokrasi, maka implementasi akan lebih efektif karena dilaksanakan oleh organisasi yang kompeten dan kapabel.

\section{METODE PENELITIAN}

Penelitian ini menggunakan pendekatan deskriptif kualitatif karena lebih menekankan pada prosedur analisis data seperti wawancara dengan informan, kajian terhadap berbagai bahan tertulis seperti dokumen, buku, dan lain-lain. Melalui pendekatan ini peneliti berupaya untuk meneliti secara intensif tanpa adanya pembatasan pengukuran. Pendekatan ini digunakan karena sangat dimungkinkan 
untuk memperoleh informasi-informasi yang baru.

Adapun teknik pengumpulan data yang digunakan dalam penelitian ini, sebagai berikut:

1. Observasi

Marshall (Sugiyono, 2010: 226) menyatakan, "Melalui observasi, peneliti belajar tentang perilaku, dan makna dari perilaku tersebut." Dalam penelitian ini, peneliti ikut terlibat dalam kegiatan sehari-hari Bagian Pelayanan Kesehatan. Dari situ dapat diperoleh data yang lengkap, tajam dan sampai mengetahui pada tingkat makna dari setiap perilaku yang nampak.

2. Wawancara

Stainback (Sugiyono, 2010: 232) mengemukakan: "Dengan wawancara, maka peneliti akan mengetahui hal-hal yang lebih mendalam tentang partisipan dalam menginterpretasikan situasi dan fenomena yang terjadi, dimana hal ini tidak bisa ditemukan melalui observasi."

Untuk mendapatkan data yang diperlukan dalam analisis permasalahan, akan diambil beberapa orang yang dijadikan sebagai informant, orang tersebut dipandang mengetahui dan terlibat dalam proses implementasi di Bagian Pelayanan Kesehatan.

3. Telaah Dokumen

Telaah dokumen merupakan pelengkap dari penggunaan metode wawancara dan observasi dalam penelitian kualitatif. Dokumen yang dapat digunakan dalam penelitian ini misalnya peraturan perundang-undangan yang berkaitan, serta dokumen-dokumen lain yang dapat mendukung terkumpulnya data penelitian menjadi lebih lengkap.

\section{PEMBAHASAN}

Kebijakan standar pelayanan kesehatan dasar pada Bagian Pelayanan Kesehatan, Biro Umum, Kementerian Sekretariat Negara di Jakarta merupakan kebijakan Menteri Sekretariat Negara yang dapat dijadikan sebagai pedoman bagi pelaksana pelayanan dan sebagai informasi bagi pengguna pelayanan mengenai pelayanan kesehatan bagi pejabat/pegawai di lingkungan Kementerian Sekretariat Negara beserta keluarganya. Dengan adanya standar pelayanan kesehatan dasar ini diharapkan dapat memperkuat sistem dan meningkatkan kinerja Bagian Pelayanan Kesehatan dalam memberikan pelayanan kesehatan, sehingga dapat mewujudkan tingkat kesehatan yang prima bagi pejabat, pegawai dan keluarga di lingkungan kementerian Sekretariat Negara.

Kebijakan standar pelayanan kesehatan dasar pada Bagian Pelayanan Kesehatan, Biro Umum, Kementerian Sekretariat Negara di Jakarta melibatkan seluruh petugas pelayanan kesehatan yang secara langsung memberikan pelayanan kesehatan dasar, Pelaksanaan standar pelayanan kesehatan dasar dipengaruhi oleh variabel penting, antara lain: komunikasi, sumber daya, disposisi dan struktur birokrasi.

\section{Aspek Komunikasi}

Kebijakan standar pelayanan kesehatan dasar pada Bagian Pelayanan Kesehatan, Biro Umum, Kementerian Sekretariat Negara di Jakarta bertujuan untuk memperkuat sistem dan meningkatkan kinerja Bagian Pelayanan Kesehatan dalam memberikan pelayanan kesehatan, sehingga dapat mewujudkan tingkat kesehatan yang prima bagi pejabat, pegawai dan keluarga di lingkungan kementerian Sekretariat Negara. Untuk mencapai tujuan dari kebijakan tersebut maka harus dikomunikasikan dengan jelas kepada pelaksana kebijakan, yaitu seluruh petugas pelayanan kesehatan .

Sementara itu banyak hal yang menyebabkan terjadinya komunikasi yang tidak konsisten dan dapat menimbulkan dampak - dampak buruk bagi implementasi kebijakan. Beberapa hal yang dimaksud antara lain: transmisi, kejelasan, dan konsistensi.

\section{a. Sub aspek Transmisi}

Berdasarkan hasil penelitian diketahui bahwa transmisi komunikasi belum berjalan dengan baik, karena 


\section{REFORMASI ADMINISTRASI}

Jurnal Ilmiah Untuk Mewujudkan Masyarakat Madani ISSN 2355-309X

sejak dikeluarkannya kebijakan mengenai standar pelayanan kesehatan dasar belum dilakukan transmisi secara menyeluruh baik kepada seluruh petugas pelayanan kesehatan maupun kepada penguna pelayanan kesehatan. Sosialisasi yang pernah dilakukan hanya sebatas kepada staf administrasi saja yang berperan dalam penyusunan standar pelayanan kesehatan dasar sedangkan sosialisasi kepada petugas yang memberikan pelayanan kesehatan belum dilakukan. Sosialisasi yang ada hanya sebatas adanya bagan alur pelayanan kesehatan yang diletakkan di ruang tunggu pasien. (lampiran. Foto Nomor 84)

Dalam penelitian ini diketahui bahwa para petugas pelayanan kesehatan memberikan pelayanan kesehatan yang mengacu pada SOP dari masing masing pelayanan yang diberikan dan mengacu pada bagan diatas dalam melaksanakan alur pelayanan kesehatan.

b. Sub aspek Kejelasan

Berdasarkan hasil penelitian yang dilakukan diketahui bahwa meskipun ada hambatan dalam proses transmisi kebijakan kepada para petugas pelayanan kesehatan namun para petugas tetap dapat memberikan kejelasan informasi kepada pengguna pelayanan melalui dua metode yaitu secara langsung dan tidak langsung yaitu melalui penjelasan secara lisan dan melalui media cetak berupa bagan alur pelayanan kesehatan dan TV. Namun pada pelaksanaanya terkadang para petugas pelayanan kesehatan belum bisa memberikan kejelasan informasi terkait pemberian pelayanan sesuai alur pelayanan kesehatan dikarenakan unsur ketidakpatuhan pengguna layanan kesehatan dalam hal ini, yaitu para pejabat. Terkadang para pejabat menginginkan pelayanan yang sangat cepat sehingga mengabaikan alur pelayanan yang ada sehingga memotong dari alur pelayanan yang seharusnya.

Di samping itu, adanya rasa takut dan segan dari para petugas pelayanan terhadap pejabat yang ingin mendapatkan pelayanan menjadi salah satu penyebab tidak sampainya kejelasan informasi terkait standar pelayanan kesehatan dasar kepada para pejabat.

c. Sub aspek Konsistensi

Hasil penelitian menunjukan bahwa standar pelayanan kesehatan dasar belum dilaksanakan secara konsisten sepenuhnya. Hal ini terjadi karena dalam menentukan konsistensi pelaksanaan standar pelayanan kesehatan dasar dilihat dari dua pihak, yaitu pemberi pelayanan dan penerima pelayanan, meskipun pemberi pelayanan sudah konsisten kebijakan standar pelayanan kesehatan tidak akan berjalan bila si penerima pelayanan tidak konsisten dalam mematuhi kebijakan tersebut.

Dalam penelitian ini diketahui bahwa tidak konsistennya pelaksanaan standar pelayanan kesehatan disebabkan oleh kurangnya ketegasan petugas pelayanan yaitu longgarnya pelaksanaan prosedur pelayanan kesehatan bagi pejabat yang menginginkan pelayanan sangat cepat dimana terkadang si pejabat tidak datang sendiri dalam meminta pelayanan kesehatan. Selain itu adanya kekosongan petugas di salah satu pelayanan mengakibatkan terlewatinya terlewatinya salah satu alur pelayanan.

2. Aspek Sumber Daya

a. Sub aspek Staf

Berdasarkan hasil penelitian ini didapatkan informasi bahwa para petugas pelayanan kesehatan telah memiliki kompetensi sesuai bidang profesinya masing-masing. Hal ini dapat dilihat dari STR yang dimiliki oleh semua petugas pelayanan kesehatan sesuai bidang profesinya. (lampiran 5). Dalam hal ini, STR 
menjadi dasar dalam pembuatan surat izin praktik tenaga kesehatan dimana STR dan SIP dari semua petugas pelayanan kesehatan diperlukan dalam proses pengurusan izin klinik.

Dalam penelitian ini diketahui bahwa semua petugas pelayanan kesehatan sudah memiliki kompetensi sesuai bidangnya yang dapat dilihat melalui STR yang dimiliki oleh para petugas. Baik STR, SIP dan izin klinik harus diperpanjang setiap lima tahun, dalam hal ini pada tahun 2016 merupakan tahun ke lima karena STR, SIP dan izin klinik sedang dalam proses perpanjangan.

Permasalahan yang dihadapi terkait dengan staff antara lain :

1) Adanya kekurangan staf pada bagian administrasi, yaitu analis perencana dan pengolah data karena pada Bagian Pelayanan Kesehatan baru ada satu staf pengolah data dan belum ada staf perencana program sementara tuntutan tugas yang terkait pekerjaan pada staf tersebut semakin kompleks.

2) Adanya kekurangan staf, yaitu perawat gigi, dengan adanya tren six handed dimana satu pasien perawatan gigi ditangani oleh satu dokter dan dua perawat untuk dapat memberikan pelayanan yang optimal dan tidak sebandingnya jumlah perawat gigi dengan jumlah dokter gigi yang ada, yaitu 2 perawat gigi dan 3 dokter gigi sehingga dibutuhkan tambahan seorang perawat gigi.

b. Sub aspek Informasi

Berdasarkan penelitian diketahui bahwa seluruh petugas pelayanan kesehatan sudah melaksanakan standar pelayanan kesehatan dasar yang mengacu pada SOP dari masingmasing pelayanan.(Lihat Lampiran 4 . Foto Nomor 80 s.d. Foto Nomor. 83). Bila dilihat dari sisi kepatuhan para petugas pelayanan terhadap jadwal pelayanan kesehatan (Lampiran 4 foto Nomor 85 s.d. Foto Nomor 86), para petugas sudah mematuhi sesuai jadwal pelayanan pada standar pelayanan kesehatan dasar bahkan lebih kompleks karena para petugas pelayanan kesehatan khususnya pada poli umum memberikan tambahan waktu pelayanan untuk kejadian yang bersifat emergency, yaitu 30 menit sebelum pelayanan dimulai dan 3 jam setelah jam pelayanan selesai. (peraturan tidak tertulis yang sifatnya emergency). Namun di sisi lain terkait kepatuhan terhadap siapa saja penerima pelayanan belum ada kekesuaian dengan standar pelayanan kesehatan dasar dimana pengguna pelayanan adalah pejabat, pegawai di lingkungan Kementerian Sekretariat Negara beserta keluarganya.

Pada pelaksanaannya Bagian Pelayanan kesehatan juga memberikan pelayanan kepada pensiunan yang sebelumnya bekerja di Kementerian Sekretariat Negara dan para tamu yang mengalami kejadian atau keadaan yang bersifat emergency pada saat berkunjung di Kementerian Sekretariat Negara. Sedangkan dalam kepatuhan terhadap penerapan syarat adminstrasi untuk memperoleh pelayanan sudah diterapkan untuk pegawai, yaitu dengan menunjukan ID Card namun untuk keluarga belum dilaksanakan dengan menunjukan Kartu Keluarga (KK).

c. Sub aspek Wewenang

Berdasarkan penelitian diketahui bahwa penanganan atau tindak lanjut terhadap adanya pengaduan/keluhan/ masukan kepada Bagian Pelayanan Kesehatan dapat disampaikan langsung kepada Kepala Bagian Pelayanan Kesehatan. Tindak lanjut terhadap adanya pengaduan/keluhan/ masukan dilakukan melalui rapat yang diadakan secara rutin sehingga adanya pegaduan/keluhan/masukan dapat dibicarakan bersama-sama dan di cari solusi penanganannya atas dasar kesepakatan bersama. (Lampiran 4. Foto Nomor 87). 


\section{REFORMASI ADMINISTRASI}

Jurnal Ilmiah Untuk Mewujudkan Masyarakat Madani ISSN 2355-309X

d. Sub aspek Fasilitas

Berdasarkan hasil penelitian dapat diketahui bahwa Bagian Pelayanan kesehatan sudah memiliki fasilitas sesuai dengan sarana dan prasarana yang tertera pada standar pelayanan kesehatan dasar (lampiran 6. Foto nomor 1 s.d nomor 53). Selain itu Bagian Pelayanan Kesehatan juga telah memiliki fasilitas sesuai dengan ketentuan Permenkes Nomor 9 Tahun 2014 Pasal 7 ayat (1) (lampiran 6. Foto nomor 63 s.d. nomor 79) dan Permenkes Nomor 9 Tahun 2014 Pasal 8 ayat (1). (lampiran 6. Foto nomor 54 s.d. nomor 62).

Selain itu pada Bagian Pelayanan Kesehatan telah dilakukan perawatan secara berkala berupa kalibrasi alat yang dilaksanakan setiap tahun dan servise dental unit yang dilaksanakan setiap bulan.

3. Aspek Disposisi

a.Sub aspek Efek Disposisi

Berdasarkan hasil penelitian diketahui bahwa para petugas pelayanan kesehatan pada umumnya sudah memiliki komitmen dan mendukung terlaksananya standar pelayanan kesehatan dasar namun komitmen dan dukungan tersebut belum sepenuhnya dilakukan. Hal tersebut terjadi pada kondisi - kondisi tertentu yang mengakibatkan terlewatinya alur proses pelayanan yang dikarenakan adanya kekosongan petugas maupun sulitnya menerapkan konsistensi pelaksanaan alur pelayanan kepada pengguna pelayanan yang menginginkan pelayanan yang sangat cepat tanpa mau mengikuti alur pelayanan.

b. Sub aspek Pengaturan Birokrasi

Berdasarkan hasil penelitian diketahui bahwa petugas pelayanan kesehatan pada Bagian Pelayanan Kesehatan terdiri dari PNS dan Tenaga Pramubakti, dan sistem pengangkatan staf berdasarkan jumlah kebutuhan pegawai sesuai dengan kompetensi dan jenis pegawai yang dibutuhkan kepada Biro Kepegawaian untuk dilakukan pengangkatan PNS. Sedangkan untuk staf dari tenaga pramubakti dapat mengajukan kebutuhan pegawai sesuai kompetensi dan jenis pegawai yang di butuhkan ke Biro Umum.

c. Sub aspek Insentif

Berdasarkan hasil penelitian dapat diketahui bahwa Bagian Pelayanan kesehatan tidak memberikan insentif kepada petugas pelayanan kesehatan dan tidak menyarankan pemberian insentif kepada petugas pelayanan kesehatan, karena pada dasarnya petugas pelayanan kesehatan yang berstatus PNS sudah menerima gaji dan remunerasi sedangkan petugas yang berstatus pramubakti sudah menerima gaji sesuai ketentuan yang berlaku.

4. Aspek Struktur Birokrasi

a. Sub aspek Standar Oprasional Prosedur (SOP)

Berdasarkan hasil penelitian diketahui bahwa pada umumnya petugas secara garis besar sudah mengerti dan melaksanakan SOP untuk mendapatkan pelayanan kesehatan sesuai Bagan Alur Pelayanan Kesehatan, di samping itu masing-masing pelayanan telah memiliki SOP dalam melaksanakan tindakan sesuai pelayanan yang diberikan.(lampiran 6. Foto nomor 80 s.d nomor 83).

b. Sub aspek Fragmentasi

Berdasarkan hasil penelitian dapat diketahui bahwa pembagian tanggungjawab terhadap pelaksanan kegiatan di poliklinik dibagi menjadi 2 bagian, yaitu di bawah Subbagian Tata Usaha dan Subbagian Pelayanan Medis. Dalam hal ini Subbagian Tata Usaha Pelayanan Kesehatan mempunyai tugas melakukan pencatatan medik, pelaporan dan urusan administasi pelayanan kesehatan. Sedangkan Subbagian Pelayanan Medis mem- 
punyai tugas memberikan dukungan administrasi pelayanan medis yang meliputi aspek promotif, preventif, kuratif dan rehabilitatif bagi pelaksanaan pelayanan kesehatan di lingkungan Kementerian Sekretariat Negara. (Lampiran 4. Foto Nomor 88). Pada pelaksanaan standar pelayanan kesehatan dasar menjadi tanggung jawab Subbagian Pelayanan Medis baik dalam hal pelaksanaan pelayanan kesehatan maupun koordinasi terkait pelaksanaan program pelayanan kesehatan. Dalam pelaksanaan program pelayanan kesehatan yang meliputi pelayanan promotif, preventif dan kuratif pada setiap awal tahun diadakan rapat koordinasi terkait rencana pelaksanaan kegiatan dan pembagian tanggung jawab dalam pelaksanaan kegiatan-kegiatan tersebut. Sedangkan pada akhir tahun dilakukan rapat evaluasi pencapaian pelaksanaan program pelayanan kesehatan untuk mengetahui sejauh mana pelaksanaan kegiatan tersebut dari masing-masing penanggung jawab serta untuk mencari solusi bila ada masalah yang berkaitan dengan pelaksanaan program pelayanan kesehatan. (Lampiran 4 Foto Nomor 89).

\section{SIMPULAN}

Berdasarkan dari hasil penelitian dan pembahasan yang telah dijabarkan pada bab sebelumnya, maka didapatkan sebuah kesimpulan bahwa implementasi Peraturan Menteri Sekretariat Negara Nomor 14 Tahun 2012 tentang Standar Pelayanan Kesehatan Dasar pada Bagian Pelayanan Kesehatan, Biro Umum, Kementerian Sekretariat Negara di Jakarta dinilai belum dilaksanakan sepenuhnya sesuai ketentuan yang ada, namun hal tersebut tidak menghambat pelaksanaan pelayanan kesehatan kepada para pejabat/pegawai beserta keluarga di Lingkungan Kementerian Sekretariat Negara. Kesimpulan tersebut dipaparkan sebagai berikut :
1. Aspek Komunikasi

Proses komunikasi sudah dilakukan namun hanya sebatas level tertentu dalam hal ini hanya dalam rapat dengan staff TU saat penyusunan standar pelayanan pelayanan kesehatan dasar. Pelaksanaan sosialisasi kepada pelaksana dilakukan hanya melalui peletakkan Bagan Alur Pelayanan Kesehatan di ruang tunggu pasien.

2. Aspek Sumber Daya

Sumber daya yang dimiliki Bagian Pelayanan Kesehatan sudah baik, hal ini dapat diketahui dengan dimilikinya staf yang sudah memiliki kompetensi sesuai bidangnya masing-masing dan fasilitas baik sarana maupun prasarana yang komplit sesuai standar pelayanan kesehatan. Namun masih terdapat kekurangan staf yaitu analis perencana, pengolah data dan perawat gigi, serta belum tersampaikannya infomasi bahwa keluarga pegawai yang ingin mendapatkan pelayanan kesehatan harus melampirkan Kartu Keluarga (KK) sebagai syarat administrasi pendaftaran.

3. Aspek Disposisi

Sikap para petugas pelayanan kesehatan pada umumnya sudah memiliki komitmen dan mendukung terlaksananya standar pelayanan kesehatan dasar namun komitmen dan dukungan tersebut belum sepenuhnya dilakukan. Dalam pengangkatan staf pada Bagian Pelayanan Kesehatan sudah sesuai kebutuhan dan sesuai dengan kompetensi serta keahlian di bidangnya. Namun Bagian Pelayanan Kesehatan tidak menerapkan sistem insentif untuk memotivasi petugas pelayanan kesehatan dalam melaksanakan kebijakan standar pelayanan kesehatan dasar.

4. Aspek Struktur Birokrasi

Secara garis besar petugas pelayanan kesehatan sudah mengerti dan melaksanakan SOP untuk mendapatkan pelayanan kesehatan sesuai Bagan Alur Pelayanan Kesehatan serta masingmasing pelayanan telah memiliki SOP dalam melaksanakan tindakan sesuai 


\section{REFORMASI ADMINISTRASI}

Jurnal Ilmiah Untuk Mewujudkan Masyarakat Madani ISSN 2355-309X

pelayanan yang diberikan. Selain itu sudah ada pembagian tanggung jawab terhadap pelaksanaan kegiatan pada Bagian Pelayanan Kesehatan yang tercermin dari struktur organisasi pada Bagian Pelayanan Kesehatan, serta sudah ada pembagian tanggung jawab dalam melaksanakan program pelayanan kesehatan yang meliputi pelayanan promotif, preventif dan kuratif yang dilaksanakan pada rapat koordinasi yang dilaksanakan di awal tahun anggaran.

\section{SARAN}

Berdasarkan kesimpulan yang telah dijabarkan, beberapa hal yang dapat disarankan dalam rangka pelaksanaan pelayanan kesehatan di Bagian Pelayanan Kesehatan adalah sebagai berikut:

1. Aspek Komunikasi

a. Sub aspek Transmisi

Perlu dilakukan sosialisasi kebijakan Permensesneg Nomor 14 Tahun 2012 terkait standar pelayanan kesehatan dasar dan mengarahkan SOP yang sudah ada pada masing-masing pelayanan agar mengacu pada ketentuan yang ada dalam standar pelayanan kesehatan.

b. Sub aspek Konsistensi

Dibutuhkan komitmen yang kuat dari seluruh petugas pelayanan kesehatan sehingga diperlukan ketegasan dari petugas pelayanan melalui pendekatan-pendekatan yang lebih mendalam, khususnya kepada para pejabat yang ingin mendapatkan pelayanan kesehatan. Sebaiknya pendekatan dilakukan oleh Kepala Bagian Pelayanan Kesehatan dan dokter karena pendekatan dan penjelasan kepada para pejabat akan lebih mudah diterima bila diberikan oleh petugas yang memiliki level jabatan atau golongan yang sama.

2. Aspek Sumber Daya

a. Sub aspek Staf

Dalam memberikan pelayanan kesehatan yang optimal sebaiknya diusahakan meminta penambahan staf pada bagian administrasi yaitu staf analisis perencana dan pengolah data serta staf pada Poli Gigi, yaitu perawat gigi.

b. Sub aspek Informasi

Dalam penyampaian informasi terkait penggunaan $\mathrm{KK}$ bagi keluarga pegawai yang ingin mendapatkan pelayanan kesehatan sebaiknya petugas pada bagian pendaftaran dapat memberikan informasi secara lisan kepada pengguna layanan.

3. Aspek Disposisi pada Sub aspek Efek Disposisi

Dalam hal ini para petugas pelayanan kesehatan harus memperbaiki koordinasi dengan petugas lainnya sehingga tidak ada kekosongan petugas di lapangan. Selain itu diharapkan para petugas pelayanan kesehatan memiliki ketegasan kepada penerima pelayanan agar mengikuti alur pelayanan kesehatan sesuai prosedur yang ada.

\section{DAFTAR PUSTAKA}

\section{BUKU}

Abdul Wahab, Solichin. 2012. Analisis Kebijakan dari Formulasi ke Penyusunan Model - Model Implementasi Kebijakan Publik. Jakarta Bumi Aksara.

Agustino, Leo. 2016. Dasa-Dasar Kebijakan Publik. Bandung: Alfabeta.

Arikunto, Suharsimi. 2007. Prosedur Penelitian Suatu Pendekatan Praktek. Jakarta: Rineka Cipta.

Creswell JW. 2010. Reseach Design Pendekatan Kuantitatif, Kualitatif dan Mixed. Edisi Ketiga. Yogyakarta: Pustaka Belajar.

Hardiyansyah. 2011. Kualitas Pelayanan Publik: Konsep, Dimensi, Indikator dan Implementasinya. Yogyakarta: Gava Media.

Nugroho, Riant. 2014. Public Policy Dinamika Kebijakan - Analisis Kebijakan - 
Indah Wahyu Maesarini dan Yuni Subiyanti, Implementasi Permensesneg No 14 Tahun 2012...

Manajemen Kebijakan. Jakarta: Elex Media Komputindo, Gramedia.

Parsons, Wayne. 2014. Public Policy: Pengantar Teori dan Praktik Analisis Kebijakan. Jakarta: Kencana Prenada Media Group.

Purwanto, Erwan Agus dan Dyah Ratih Sulistyastuti. 2012. Implementasi Kebijakan Publik: Konsep dan Aplikasinya di Indonesia. Yogyakarta : Gava Media.

Ratminto dan Atik Septi Winarsih. 2007. Manajemen Pelayanan. Yogyakarta: Pustaka Belajar.

Subarsono, AG. 2013. Analisis Kebijakan Publik: Konsep, Teori dan Aplikasi. Yogyakarta: Pustaka Pelajar.

Sugiyono. 2016. Metode Penelitian Kuantitatif, Kualitatif dan R\&D. Bandung: Alfabeta.

Tahir, Arifin. 2014. Kebijakan Publik \& Transparansi: Penyelenggaraan Pemerintah Daerah. Bandung: Alfabeta.

Winarno, Budi. 2014. Kebijakan Publik: Teori, Proses \& Studi Kasus. Yogyakarta: Center of Academic Publishing Service.

\section{PERATURAN}

PERUNDANG-

UNDANGAN

Peraturan Menteri Sekretaris Negara Nomor 14 Tahun 2012 tentang Standar Pelayanan Unit Kerja di Lingkungan Kementerian Sekretariat Negara Republik Indonesia.
Peraturan Menteri Sekretaris Negara Nomor 3 Tahun 2015 tentang Organisasi dan Tata Kerja Kementerian Sekretariat Negara.

Peraturan Menteri Kesehatan Republik Indonesia Nomor 46 Tahun 2013 tentang Registrasi Tenaga Kesehatan.

Peraturan Menteri Kesehatan Republik Indonesia Nomor 9 Tahun 2014 tentang Klinik.

\section{SUMBER LAIN}

Shadikin. 2014. Implementasi Standar Pelayanan Kesehatan di Puskesmas Barong Tongkok Kabupaten Kutai Barat.[Online].Available:http://ejournal.a n.fisip-unmul.ac.id/site/wpcontent/uploads/2014/02/3.\%20dikin\%20 jurnal\%20(02-14-14-02-59-06).pdf, diakses 13 September 2016.

Khozin, Mohammad. 2010. Evaluasi Implementasi Kebijakan standar Pelayanan Minimal Bidang Kesehatan di Kabupaten Gunung Kidul. [Online].Available:http://journal.umy.ac.i d/index.php/jsp/article/view/177/516, diakses 15 September 2016.

Saputra, Dedi Rahmat. 2014. Implementasi Standar Pelayanan Minimal Bidang Kesehatan di RSUD Kota Baubau. [Online].Available:http://thesis.umy.ac.id /datapublik/t42800.pdf, diakses 16 September 2016. 